University of Nebraska - Lincoln

DigitalCommons@University of Nebraska - Lincoln

Agronomy \& Horticulture -- Faculty Publications

Agronomy and Horticulture Department

1987

\title{
Evaluation of Repellent Seed Treatments and Effects on Early Corn Performance
}

\author{
Ann E. Koehler \\ University of Nebraska-Lincoln \\ Ron J. Johnson \\ University of Nebraska-Lincoln, ronj@clemson.edu \\ Orvin C. Burnside \\ University of Minnesota - Twin Cities \\ Stephen R. Lowry \\ University of Kentucky
}

Follow this and additional works at: https://digitalcommons.unl.edu/agronomyfacpub

Part of the Agricultural Science Commons, Agriculture Commons, Agronomy and Crop Sciences Commons, Botany Commons, Horticulture Commons, Other Plant Sciences Commons, and the Plant Biology Commons

Koehler, Ann E.; Johnson, Ron J.; Burnside, Orvin C.; and Lowry, Stephen R., "Evaluation of Repellent Seed Treatments and Effects on Early Corn Performance" (1987). Agronomy \& Horticulture -- Faculty Publications. 1040.

https://digitalcommons.unl.edu/agronomyfacpub/1040

This Article is brought to you for free and open access by the Agronomy and Horticulture Department at DigitalCommons@University of Nebraska - Lincoln. It has been accepted for inclusion in Agronomy \& Horticulture -Faculty Publications by an authorized administrator of DigitalCommons@University of Nebraska - Lincoln. 
Ann E. Koehler, ${ }^{1}$ Ron J. Johnson, ${ }^{2}$ Orvin C. Burnside, ${ }^{3}$ and
Stephen R. Lowry

\title{
Evaluation of Repellent Seed Treatments and Effects on Early Corn Performance ${ }^{5}$
}

\begin{abstract}
REFERENCE: Koehler, A. E., Johnson, R. J., Burnside, O. C., and Lowry, S. R., "Evaluation of Repellent Seed Treatments and Effects on Early Corn Performance," Vertebrate Pest Control and Management Materials: 5th Volume, ASTM STP 974, S. A. Shumake and R. W. Bullard, Eds., American Society for Testing and Materials, Philadelphia, 1987, pp. 39-51.

ABSTRACT: A combination of field, field enclosure, and germination chamber studies was used to evaluate the effects of methiocarb [3,5-dimethyl-4-(methylthio)phenol methylcarbamate] and thiram (tetramethylthiuram disulfide) repellent seed treatments on early corn performance. The thiram treatments used $(0.08,0.4,0.8,0.5,1.25$, and $2.5 \%$ active ingredient by corn seed weight) had negligible effects on germination/emergence time or on corn plant heights. The thiram treatments never reduced stand counts in comparison to controls, but apparently increased stand counts in some trials, particularly under wet conditions. The methiocarb treatments evaluated $(0.5,1.25,2.5$, and $5.0 \%$ active ingredient by corn seed weight) had only occasional effects on early corn performance. However, certain methiocarb treatments advanced or retarded germination in some trials and increased plant heights in three trials. Methiocarb treatments did not affect corn stand counts in most trials, but increased or reduced stand counts in some. The reduced stand counts appear related to wet conditions and possibly to other field effects. The techniques used have application in studies of both plant and rodent responses to seed-treatment repellents.
\end{abstract}

KEY WORDS: vertebrate pest control, wildlife damage control, bird, rodent, chemical repellent, technique, field enclosure, germination chamber, methiocarb, Mesurol, thiram, plant growth, seed germination, sprout emergence, corn

Linehan [1] presented a field-enclosure technique for evaluating bird-repellent seed treatments applied to corn seed and suggested that the technique might be adaptable to rodent studies. He demonstrated that the technique allowed greater control of several variables that often cause problems in field evaluations of repellents. Advantages included the capability of testing several treatments in a single test, ability to control feeding pressure, more uniform conditions in tests, ability to distinguish wildlife damage from disease and insect damage, and ability to accurately measure effects on plant performance in addition to repellency effectiveness. However, for use with rodents, modifications were needed to prevent rodent escape and to

'Graduate research assistant, Department of Forestry, Fisheries, and Wildlife, University of Nebraska, Lincoln, NE 68583-0819; presently graduate student in Wildlife and Fisheries Biology, University of California, Davis, CA 95616.

${ }^{2}$ Extension wildlife specialist and associate professor, Department of Forestry, Fisheries, and Wildlife, University of Nebraska, Lincoln, NE 68583-0819.

${ }^{3}$ Professor, Department of Agronomy, University of Nebraska, Lincoln, NE 68583-0915; presently head, Department of Agronomy and Plant Genetics, University of Minnesota-Twin Cities, St. Paul, MN 55108.

${ }^{4}$ Associate professor, Biometrics and Information Systems Center, University of Nebraska, Lincoln, NE 68583-0712; presently assistant director, Agricultural Experiment Station, University of Kentucky, Lexington, KY 40546-0091.

${ }^{5}$ Published as Journal Series No. 7436, Agricultural Research Division, University of Nebraska-Lincoln. 
consider various aspects of rodent biology. In this paper, we describe experiments that adapt this technique to evaluation of rodent-repellent seed treatments and, along with open-field trials and germination chamber studies, provide data on treatment effects on early corn performance.

\section{The Problem}

Repellent seed treatments containing methiocarb are commonly used to protect sprouting corn from damage by birds [2-4], a problem that can result in stand losses $\geq 50 \%$ [3]. Both methiocarb and thiram seed treatments have been investigated as repellents to prevent the increasingly evident problem of rodent damage to newly planted corn in conservation-tillage fields $[5,6]$. The extent of this rodent damage is variable but may result in stand losses of $\geq 25 \%$ in some fields and may necessitate replanting $[7,8]$. Methiocarb is used in some states under Special Local Needs (24c) registrations to control this type of rodent damage. Thiram is federally registered in the United States as a fungicide and repellent, but the registered rate for corn seed is a fungicide rate, which is lower than the rate reported effective in repelling certain rodents [5].

Currently, there is little published information available on how these seed treatments affect corn plants, and the phytotoxicity data available are presented as incidental to other data on repellency. Therefore, data are needed to document more clearly whether these chemicals are phytotoxic to corn and, if so, under what conditions phytotoxicity is likely to occur. Such data would allow producers and others to better evaluate the risks and benefits of using these chemicals as repellents. The techniques used allowed examination of the effects of methiocarb and thiram seed treatments on corn performance, in addition to evaluation of treatment effectiveness in repelling rodents. This paper describes treatment effects on corn germination/emergence, plant growth, and stand counts, and compares the results with limited results available from other studies. Details of thirteen-lined ground squirrel (Spermophilus tridecemlineatus) responses to the repellents are described elsewhere [5].

\section{Materials and Methods}

\section{Treatments}

Methiocarb [Mesurol 50\% Hopper-Box Treater (HBT) or Mesurol Wettable Powder (WP); Mobay Chemical Corp., Kansas City, MO] and thiram (Gustafson 42-S Fungicide and Repellent Liquid; Gustafson, Inc., Dallas, TX) seed treatments were evaluated during 1981, 1982, and 1983. Treatment levels are expressed as percent active ingredient by corn seed weight. An untreated control was included in all trials and a sticker-control was included in trials with methiocarb HBT rates of $1.25 \%$ or higher; at these higher rates, a sticker (Wilt Pruf, Greenwich, CT) was required to adhere the chemicals to the seed. Further details of treatment preparation are available elsewhere [5]. Corn varieties used were "Nebraska 611" (coated with Captan Seed Protectant 30\%; $0.3 \mathrm{~g}$ active Captan per kg corn) in 1981, untreated "Northrup King PX.74" in 1982, and untreated "NC+ Hybrid 4695" in 1983.

\section{Field and Field-Enclosure Studies}

All field studies (field and field enclosure trials) were conducted at the University of Nebraska-Lincoln Agronomy Farm in Lancaster County, Nebraska. The soil at this site is a Sharpsburg silty clay loam (Typic Argiudoll) with 3\% sand, $58 \%$ silt, $39 \%$ clay, $3.2 \%$ organic matter, $6.5 \mathrm{pH}$, and $17 \mathrm{meq}$ cation exchange capacity.

Field Trials-All field trials contained four replicate plots per treatment. Each plot consisted of six 15.2-m rows during 1981 trials, six 9.1-m rows during 1982 trials, and ten 9.1-m rows 
during 1983 trials. Data evaluating treatment effects on corn were collected in conjunction with repellency experiments, and the plot size modifications among years reflect efforts to increase the potential for rodent damage [9]. Three trials were planted in 1981, three in 1982, and four in 1983.

Treatment effects on plant performance were evaluated from emergence data (collected in 1982 and 1983 only), stand counts (in the absence of rodent or bird damage), and plant heights. A plot was considered emerged when an average of twelve plants per row $(50 \%$ of the expected stand) were visible in the inner four (1982) or eight (1983) rows. Inner rows were selected to avoid border effects. Stand count and plant height data were collected after the corn was circa $13 \mathrm{~cm}$ high (circa 18 days after planting, weather permitting) and no longer susceptible to rodent damage. Stand counts were made of all corn plants in the inner four (1981 and 1982) or eight (1983) rows. Plant heights were measured from the base to the extended tip of the longest leaf. Five (1981) or ten (1982 and 1983) randomly selected plants were measured in the inner two (1981 and 1982) or four (1983) rows, thus totaling 10 plants per plot measured in 1981 trials, 20 per plot in 1982, and 40 per plot in 1983.

Field-Enclosure Trials-Two field enclosures of galvanized wire mesh $(1.3$ by $2.5 \mathrm{~cm})$ were constructed in the same area as the field trials: one in 1981 (13.7 by 6.4 by $1 \mathrm{~m}$ ) with room for up to eight treatments per trial (four replicate plots each) and a second in 1982 (14.0 by 10.8 by $1 \mathrm{~m}$ ) with room for up to ten treatments. The perimeter walls of the enclosures were extended $0.9 \mathrm{~m}$ below ground (small enclosure) or $0.7 \mathrm{~m}$ below ground with a $0.2-\mathrm{m}$ inward-directed lip (large enclosure) to prevent ground squirrels from escaping by burrowing. In addition, tops were constructed over the enclosures to prevent loss of ground squirrels to aerial predators and to prevent bird depredation of corn seed. To prevent ground squirrel escape, the top of the small enclosure was made of galvanized wire mesh $(1.3 \mathrm{by} 2.5 \mathrm{~cm})$ with steel posts used for interior support. The large enclosure was improved by using a top of lightweight fiber netting $(2.5-\mathrm{cm}$ mesh), which was easier to install and work under; $37-\mathrm{cm}$ aluminum flashing was riveted along the top edge of the perimeter walls to prevent ground squirrels from climbing out through the netting. Two acclimation areas were provided in each enclosure by constructing partitions of wire mesh (1.3 by $2.5 \mathrm{~cm}$ ) across the width of each enclosure $1.5 \mathrm{~m}$ from each end. One or two $0.5-\mathrm{m}$ artificial burrows were installed in each acclimation area.

Within the enclosures, each plot consisted of two parallel rows of 24 seeds each, planted $5 \mathrm{~cm}$ deep through a template with holes spaced $7.6 \mathrm{~cm}$ apart. One row of each plot was enclosed with galvanized hardware cloth on all sides to exclude rodents, an arrangement that allowed evaluation of treatment effects on plant performance (covered row) separate from the evaluation of repellency (uncovered row) [1]. Each treatment was planted in a single plot per replication during most trials. However, during the final 1982 trial (planted 9 Aug.) and all 1983 trials, each treatment was planted in three (larger enclosure) or two (smaller enclosure) plots per replication. Four trials were planted in 1981, five in 1982, and four in 1983. To ensure germination or corn survival during dry weather, plots were irrigated as needed prior to or during some trials.

An enclosure plot was considered emerged when twelve plants $(50 \%)$ were visible in the covered row. Stand counts were made of all covered-row plants, and heights of ten randomly selected plants were measured in each covered row. Results of rodent damage to uncovered rows are reported elsewhere [5].

Weather Data-Soil temperatures (10 cm depth under bare soil) for 1981 and 1982 were obtained from the nearest weather station with such data, located circa $35 \mathrm{~km}$ north northeast of the research site (Automated Weather Data Network, Mead Station) [10]. Soil temperatures for 1983 were obtained from a weather station established at the Lincoln Agronomy Farm that year (Havelock Station) [10]. Precipitation was measured with rain gages at the Agronomy Farm except for June, July, and August 1981 when rainfall data from the Lincoln Airport Weather Station, circa $12 \mathrm{~km}$ west of the research site, were used [11]. Although portions of the weather data were not taken directly at the Agronomy Farm, comparisons of periods with overlapping data indicate that the differences were not sufficient to affect the outcome of this study. 


\section{Laboratory Studies}

Treatment effects on corn were also evaluated using germination chambers. Four trays, each with ten seeds on moistened germination paper, were prepared for every treatment. One tray of each treatment was randomly positioned within each of four chambers. Chamber conditions were $20^{\circ} \mathrm{C}$ for $8 \mathrm{~h}$ of fluorescent light and $10^{\circ} \mathrm{C}$ for $16 \mathrm{~h}$ of darkness (one trial, 1982) and $25^{\circ} \mathrm{C}$ for $8 \mathrm{~h}$ of light and $15^{\circ} \mathrm{C}$ for $16 \mathrm{~h}$ of darkness (one trial each, 1982 and 1983). Relative humidity was circa $100 \%$ during all trials.

Seeds were examined daily to determine germination time for each tray (when the radicle from five of the ten seeds became visible). Plant length, from the tip of the main root to the top of the shoot, was measured for each sprout every three days beginning three days after germination and continuing until five sets of measurements were recorded per tray. Sprout survival, the total number of sprouts surviving at the end of a trial ( 15 days after the germination time), was also recorded for each tray.

\section{Analysis}

All trials were arranged in a randomized complete block design with four replications. Experiments were analyzed using analysis of variance. Dunnett's test [12] was used to compare each treatment to the control. Data were evaluated at the 0.05 level of significance.

\section{Results}

\section{Emergence/Germination}

Of four field and five enclosure trials for which emergence data were obtained, treatment emergence dates differed from the control in only two enclosure trials (Table 1). During the 12 June 1982 trial, the $2.5 \%$ methiocarb HBT/S treatment emerged later than did the control, but during the 13 June 1982 trial, the $0.5 \%$ methiocarb HBT-treated corn emerged earlier.

Of the three germination chamber trials, differences in germination time were found only during the trials conducted under warmer conditions. In the 1982 trial, the control germinated earlier than the $0.5 \%$ methiocarb HBT treatment, but no other treatments differed from the control. During the 1983 trial, germination time for the control did not differ from that of $0.5 \%$ methiocarb HBT or sticker-control but was later than all other treatments.

\section{Plant Growth}

Treatment mean plant heights differed from the control during only one of ten field trials (Table 2). In that trial (10 May 1983), 1.25\% thiram- and 0.5\% methiocarb HBT-treated corn grew taller than did the control.

Differences in mean plant height between treatments and the control were detected in 2 of 13 enclosure trials. In the $6 \mathrm{May} 1981$ trial, 2.5\% methiocarb HBT/S-treated corn grew taller than did the control. In the 21 Aug. 1981 trial, corn treated with methiocarb HBT $(0.5 \%$ or $2.5 \% / S)$ and corn treated with the sticker grew taller than did the control. In the three chamber trials, no differences in mean plant length were detected in comparisons of the treatments to the control.

\section{Stand Counts}

Stand counts differed between the control and treatment in 5 of 10 field trials and in 4 of 13 enclosure trials (Table 3). In the 7 May (field) and 4 June (enclosure) 1981 trials, two methiocarb HBT/S treatments $(2.5$ and $5.0 \%$ ) had higher mean stand counts than did the control. Similarly, methiocarb field plots that were planted on 10 May $(0.5 \%$ HBT) or 22 June 


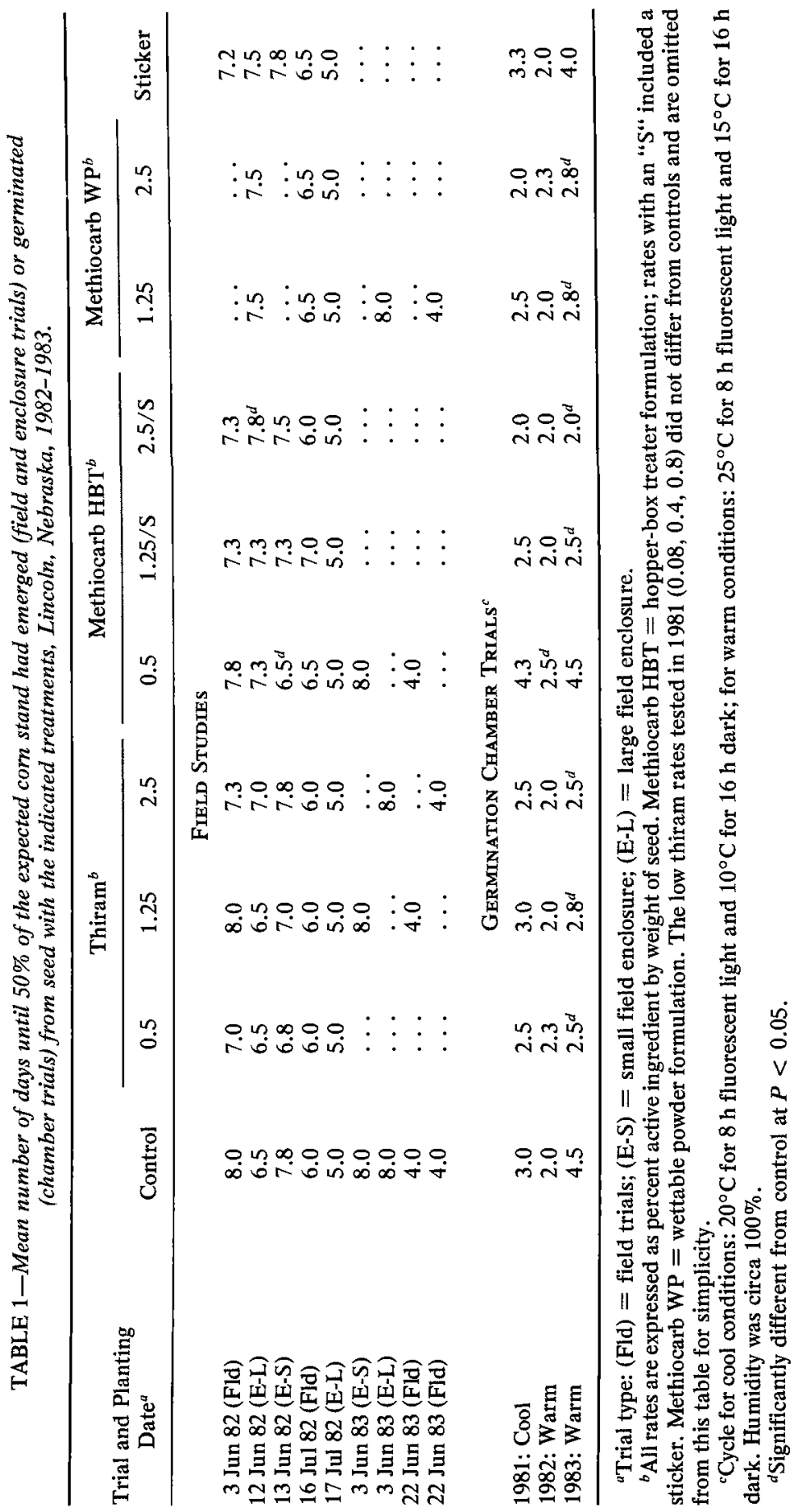




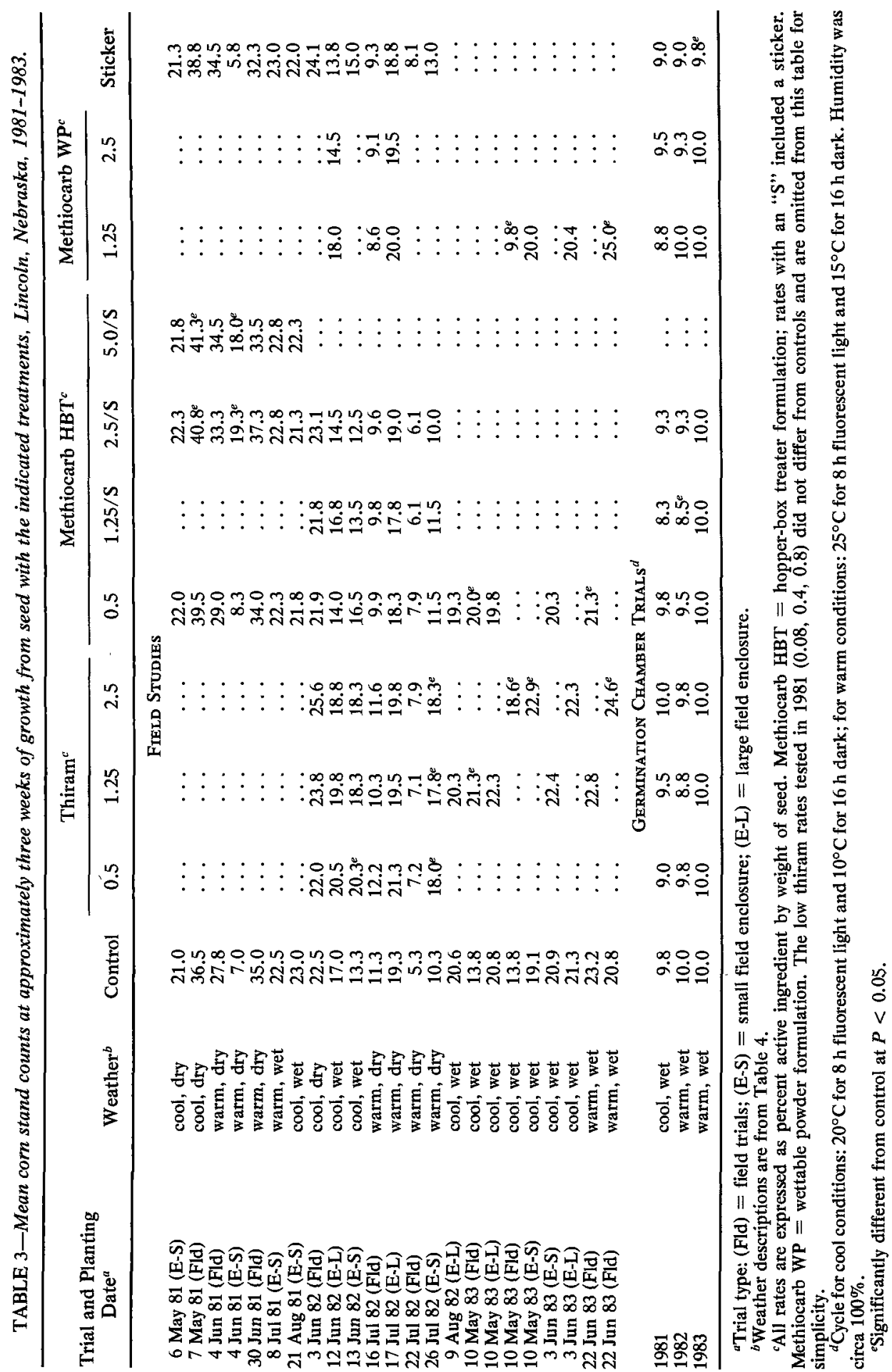


(1.25\% WP) 1983 had higher mean stand counts than did controls. In contrast, methiocarb plots that were planted in a different, less well-drained field on 10 May (1.25\% WP) or 22 June $(0.5 \%$ HBT) 1983 had lower mean stand counts than did controls. May and June 1983 had unusually wet weather conditions (Table 4). Thiram-treated plots had greater mean stand counts than did control plots in three field trials and three enclosure trials (Table 3); five of these six trials received high amounts of rainfall (Table 4).

In germination chamber studies, differences in survival counts were detected between treatments and the control in two trials. In the 1982 trial (warmer conditions), mean survival of $1.25 \%$ methiocarb HBT/S-treated corn was less than the control. This difference resulted primarily from unusually low survival for $1.25 \%$ methiocarb $\mathrm{HBT} / \mathrm{S}$ in one replication in which only seven of ten methiocarb HBT/S sprouts survived as compared to nine sprouts in the other three replications. During the 1983 trial (warmer conditions), mean survival count for the sticker-control was lower ( 0.2 days) than the control.

\section{Discussion}

\section{Techniques Used}

One difficulty in field studies of repellents pointed out by Linehan [1] is that such studies often provide little information on how chemicals influence germination and plant performance, a point also evidenced by the lack of such information in the literature. In our experiments, the use of small but carefully monitored field and enclosure plots provided complimentary data on plant performance that was further enhanced by data from germination chambers with controlled environmental conditions. Another difficulty encountered in field repellency studies is unpredictability and variability in feeding pressure among treatments [1]. As example, our open-field trials received essentially no rodent damage even though the area had a history of rodent damage problems [9]. Thus, the open-field plots provided additional data on plant performance effects but no data on repellency of treatments to rodents. Had the openfield plots received considerable rodent damage, remaining plant stands might have been insufficient to evaluate plant performance effects. The field-enclosures provided data on both repellency to rodents [5] and effects on plants.

One possible disadvantage of enclosures is that shade from the wire or netting might result in cooler or wetter soil than occurs in open field situations and thus slow germination or reduce stand counts for some treatments. Such conditions are not limited to enclosures, of course, but awareness of possible shading effects is recommended in designing trials and interpreting data. Although our observations of covered versus uncovered rows in trials reported here indicated no noticeable shading effects, treatment comparisons were made only among plots with similar cover, for example, covered-row data were compared to other covered-row data. Moreover, enclosure trials were conducted under a range of temperature and moisture conditions to ensure that a range of conditions similar to those in open fields was included.

The 1.3 by $2.5 \mathrm{~cm}(0.5$ by $1 \mathrm{in}$.) wire used to construct our enclosures apparently excluded other rodents such as deer mice (Peromyscus maniculatus) that also damage newly planted corn [13]. Although some such rodents might have been physically able to squeeze through the wire, we saw no evidence during trials that they had nor damage typical of these species.

Overall, it appears that combinations of the three techniques used, field, enclosure, and chamber trials, provide the most useful data in evaluating repellent seed-treatments. However, the field enclosure technique alone appears to have the greatest potential for supplying meaningful and significant data in rodent repellency studies. 


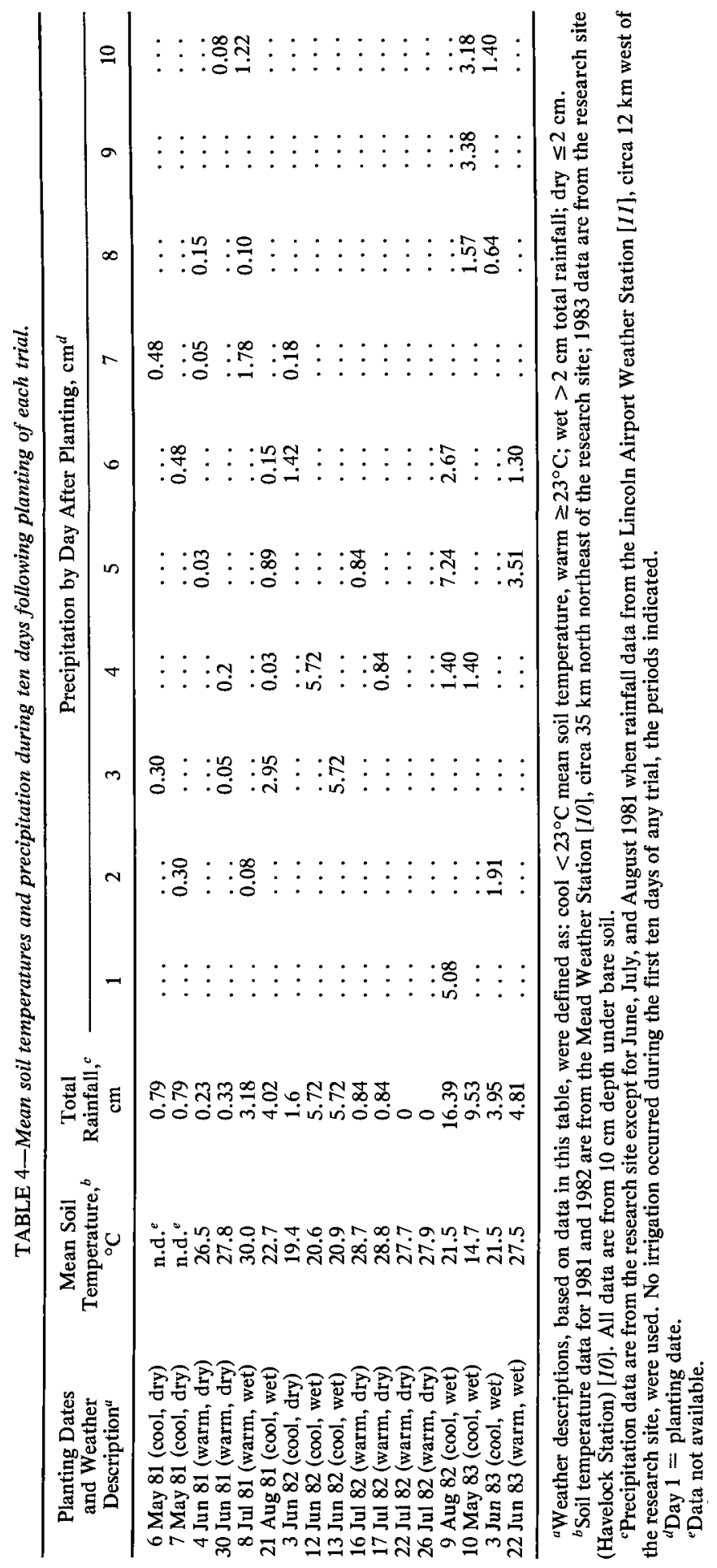




\section{Effects on Plant Performance}

Decisions regarding use of repellent seed treatments to prevent bird or rodent damage to sprouting corn should include not only repellent efficacy and likelihood of damage, but also treatment effects on plant performance. Regarding thiram, our results indicate that the treatments used have negligible effects on germination/emergence time and on corn plant heights. Additionally, the thiram treatments never reduced stand counts in comparison to controls, but the $0.5,1.25$, and $2.5 \%$ levels apparently increased stand counts during several trials, particularly under wet conditions. Fungicidal properties of thiram may have contributed to these higher mean stand counts, especially considering that they occurred during 1982 and 1983, years in which the seed had not been pretreated with a fungicide (Captan) as had the corn in 1981.

West $^{6}$ reported that corn seed treated with $3 \%$ thiram had lower germination than controls in a germinator (conditions unspecified), but that it produced higher stand counts in field trials. Our germination chamber results differ from those of West, but he used a higher rate and chamber conditions may have differed. His field results are consistent with ours. Linehan [1] reported slightly reduced corn stand counts in field enclosure trials using seed treatments of 2.5 and $10 \%$ (percent "actual" of seed weight) Arasan (thiram), (0.8 and $2.1 \%$ lower than controls, respectively). However, he found no reduction in germination when using these treatments in laboratory germination tests (conditions unspecified). Linehan's findings may have resulted from the different rates used or field conditions. Overall, our results with thiram are consistent with these other reports. Thus, at the rates we tested, phytotoxicity does not appear to limit the potential development of thiram as a seed-treatment repellent for corn.

Regarding methiocarb, the rates we evaluated appeared to have little overall effect on germination/emergence time. Although germination was advanced with methiocarb treatment in two trials (one enclosure, one chamber) and retarded in two trials (one enclosure, one chamber), it did not differ from control in most trials. These results are consistent with those of Heisterberg, ${ }^{7}$ who found no retarded or advanced corn seed germination from treatment effects of methiocarb $(0.25$ and $0.5 \%)$. Additionally, Fuller et al. [14] reported that methiocarb at rates up to $4 \%$ did not delay germination of conifer seeds in laboratory trials.

Our plant height/length data for methiocarb provided no evidence that methiocarb negatively affected corn growth at the rates tested, but indicated that some treatments may enhance growth under certain conditions. These findings are similar to those of Hermann and Kolbe [15], who found no plant height differences between untreated and $0.5 \%$ methiocarb-treated corn. Duncan [16] noted increased plant heights in grain sorghum sprayed with 1.2 or 2.4 $\mathrm{kg} / \mathrm{ha}$ of methiocarb WP during the grain-filling stage, but no difference from control was observed using $4.2 \mathrm{~kg} / \mathrm{ha}$. In contrast, West ${ }^{8}$ reported that the rate of growth for methiocarbtreated $(3 \%)$ corn was markedly slower than for control in a germinator, but that there was no indication of such slow growth in fields.

Our stand count results from methiocarb treatments indicate that corn stand counts generally are not affected, although increased or reduced stand counts may occur under certain conditions. Increased stand counts with methiocarb treatment were observed in three trials (two field, one enclosure) and reduced counts in three trials (two field, one chamber). West et al. [17] found that methiocarb $(0.5 \%)$ treatments apparently increased the number of corn plants in field studies and suggested that this may have resulted because of methiocarb's insecticidal properties. Stickley and Guarino [18] also noted higher stand counts in methiocarb-treated

${ }^{6}$ R. R. West, U.S. Fish and Wildlife Service, Denver Wildlife Research Center, Denver, CO, unpublished data, October 1966.

${ }^{7}$ J. F. Heisterberg, U.S. Fish and Wildlife Service, Denver Wildlife Research Center, Bowling Green, KY 42101, personal communication, 1980.

${ }^{8}$ R. R. West, U.S. Fish and Wildlife Service, Denver Wildlife Research Center, Denver, CO, unpublished data, October 1966. 
$(0.5 \%)$ plots, but the difference was not significant. West ${ }^{9}$ reported a slight reduction in germination (stand count) in two of three fields from seed treated with $3 \%$ methiocarb, but felt that poor farming practices contributed to the reduced stand in the two fields. Linehan et al. ${ }^{10}$ reported $24 \%$ lower corn stand counts compared with controls in methiocarb HBT-treated $\mathbf{( 0 . 5 \% )}$ fields in Delaware and suggested that these results occurred because of cool wet (unspecified) conditions during the study. Heisterberg ${ }^{11}$ found no differences in corn stand counts among methiocarb HBT-treated $(0.25$ and $0.5 \%)$ plots and controls, but noted that cool wet weather did not occur during his study.

There is clear evidence that certain methiocarb treatments may affect corn stand counts under some conditions, but the reasons or conditions are not clear. Cool temperatures apparently are not always necessary for reduced stand counts to occur; our 22 June 1983 trial had reduced stands and warm $\left(27.5^{\circ} \mathrm{C}\right)$ soil conditions. However, wet conditions may be associated with reduced stand counts from methiocarb treatments. In all cases in which lower stand counts occurred in our trials, we had fairly wet conditions.

Variations in soil drainage or nutrient composition may affect seed response to methiocarb treatment. Our 10 May and 22 June 1983 field trials appeared to have such a field effect. Duncan and Boswell [19] reported that methiocarb WP-treated (1.2 kg/ha) sorghum had, in comparison to controls, reduced seed concentrations of $\mathrm{N}, \mathrm{K}, \mathrm{Mn}$, and $\mathrm{Cu}$, but increased $\mathrm{P}$. Perhaps the variability in methiocarb effects on early corn performance results from effects on chemical composition of the seed in conjunction with environmental conditions.

Finally, different corn varieties may respond differently to methiocarb treatment. Hermann and Kolbe [15] reported that in growers' usage tests, one corn variety, because of its slow early growth in cold spring weather, lacked "tolerance" to methiocarb $(0.5 \%)$ treatment. They recommended that growers avoid this variety and that they establish optimal conditions for emergence and early plant growth. The corn variety we used in 1983 (NC+ Hybrid 4695) had stand counts both higher and lower than controls, an apparent field effect. The variety used in our 1982 warm-condition chamber trial (Northrup King PX.74) had lower counts with one methiocarb treatment. It seems likely that in our studies factors other than corn variety were associated with these stand count differences.

\section{Conclusion}

Methiocarb seed treatments will continue to be of importance as nonlethal repellents to protect sprouting corn from bird damage, and, following further development, both methiocarb and thiram may become useful as repellents to protect newly planted corn from rodent damage in conservation-tillage fields. This paper is the first to present numerical data focusing particularly on how these seed treatments affect early corn performance. Results from trials conducted under a variety of conditions indicate that generally no negative effects will occur; however, under wet conditions in some fields, methiocarb seed treatments may cause reduced stand counts. Our data indicate no correlation between reduced stand counts with methiocarb treatments and soil temperatures. Further documentation of conditions associated with these stand count effects and evaluation of methiocarb effects on chemical composition of the seed may lead to more accurate predictability. Although the factors noted should be considered, it appears that the potential for negative effects from thiram or methiocarb seed-treatments is not sufficient to prevent their use and/or development as repellent seed treatments.

${ }^{9}$ R. R. West, U.S. Fish and Wildlife Service, Denver Wildlife Research Center, Denver, CO, unpublished data, October 1966.

${ }^{10}$ J. T. Linehan, C. R. Ingram, and P. W. Lefebvre, U.S. Fish and Wildlife Service, Denver Wildlife Research Center, Denver, CO, unpublished data, June 1975.

"J. F. Heisterberg, U.S. Fish and Wildlife Service, Denver Wildlife Research Center, Bowling Green, KY 42101, personal communication, 1980. 
The techniques described, particularly the field enclosures, were effective in testing seedtreatment repellents. These results, in conjunction with those of Linehan [1], indicate that fieldenclosure techniques minimize many difficulties associated with field repellency tests and are usable for both bird and rodent studies.

\section{Acknowledgments}

We are grateful to D. Bichlmeier, M. Golden, K. Holm, N. Kemble, T. Labedz, T. Malchow, D. Todd, K. Watteyne, and personnel at the Lincoln Agronomy Farm for research assistance, and to L. Nearman and E. Moore for materials. We also thank R. Case and J. Brandle for review of the manuscript and project advice; $S$. Kamble for administrative assistance; $M$. Beck, R. Timm, and anonymous reviewers for comments on the manuscript; and J. Andelt, L. Hanna, and P. Lionberger for technical assistance. Funding for this project was provided in part by the North Central Regional Pesticide Impact Assessment Program and the National Agricultural Pesticide Impact Assessment Program (NAPIAP) of the U.S. Department of Agriculture. However, any opinions, findings, conclusions, or recommendations expressed in this publication are those of the authors and do not necessarily reflect the view of the U.S. Department of Agriculture.

\section{References}

[1] Linehan, J. T., "Improving Efficacy Testing of Bird-Repellent Seed Treatments," Vertebrate Pest Control and Management Materials, ASTM STP 680, American Society for Testing and Materials, 1979, pp. 217-230.

[2] Guarino, J. L., "Methiocarb, a Chemical Bird Repellent: a Review of its Effectiveness on Crops," Proceedings, Vertebrate Pest Conference, Vol. 5, 1972, pp. 108-111.

[3] Stone, C. P. and Mott, D. F., "Bird Damage to Sprouting Corn in the United States," Special Scientific Report-Wildlife No. 173, U.S. Fish and Wildlife Service, Washington, DC, 1973.

[4] Dolbeer, R. A., "Blackbirds," in Prevention and Control of Wildlife Damage, R. M. Timm, Ed., Great Plains Agricultural Council and University of Nebraska, Lincoln, NE, 1983, pp. E1-E14.

[5] Johnson, R. J., Koehler, A. E., Burnside, O. C., and Lowry, S. R., "Response of Thirteen-lined Ground Squirrels to Repellents and Implications for Conservation Tillage," Wildlife Society Bulletin, Vol. 13, No. 3, 1985, pp. 317-324.

[6] Johnson, R. J., "Repellents for Rodents in Conservation-Tillage Agriculture," Proceedings, Eastern Wildlife Damage Control Workshop, Vol. 2, 1985, pp. 66-72.

[7] Johnson, R. J., Koehler, A. E., and Burnside, O. C., "Rodent Repellents for Planted Grain," Proceedings, Vertebrate Pest Conference, Vol. 10, 1982, pp. 205-209.

[8] Johnson, R. J., "Wildlife Damage in Conservation Tillage Agriculture: a New Challenge," Proceedings, Vertebrate Pest Conference, Vol. 12, 1986, pp. 127-132.

[9] Koehler, A. E., "Methiocarb and Thiram as Thirteen-lined Ground Squirrel Repellents in Newly Planted Corn," M.S. thesis, University of Nebraska, Lincoln, NE, 1983.

[10] Hubbard, K. G., Rosenberg, N. J., and Nielsen, D. C., "Automated Weather Data Network for Agriculture," Journal of Water Resource Planning and Management, Vol. 109, No. 3, 1983, pp. 213-222.

[11] "Local Climatological Data for Lincoln, Nebraska, Municipal Airport," National Oceanic and Atmospheric Administration, National Climatic Data Center, Asheville, NC, 1981.

[12] Steel, R. G. D. and Torrie, J. H., Principles and Procedures of Statistics, 2nd ed., McGraw-Hill, New York, 1980.

[13] Holm, K. E., "Small Mammal Populations and Rodent Damage in Notillage Crop Fields," M.S. thesis, University of Nebraska, Lincoln, NE, 1983.

[14] Fuller, R., Landis, T., Cummings, J., and Guarino, J., "Mesurol 75\% Seed Treater as a Bird Repellent Seedcoat Treatment," Tree Planters Notes, Vol. 35, No. 1, 1984, pp. 12-17.

[15] Hermann, B. and Kolbe, W., "Effect of Seed Coating with Mesurol for Protection of Seed and Sprouting Maize Against Bird Damage, with Consideration to Varietal Tolerance and Side-effects," Pflanzenschutz-Nachrichten, Vol. 24, No. 2, 1971, pp. 279-320. 
[16] Duncan, R. R., "Methiocarb as a Bird Repellent on Ripening Grain Sorghum," Canadian Journal of Plant Science, Vol. 60, 1980, pp. 1129-1133.

[17] West, R. R., Brunton, R. B., and Cunningham, D. J., "Repelling Pheasants from Sprouting Corn with a Carbamate Insecticide," Journal of Wildlife Management, Vol. 33, No. 1, 1969, pp. 216-219.

[18] Stickley, A. R., Jr. and Guarino, J. L., "A Repellent for Protecting Corn Seed from Blackbirds and Crows," Journal of Wildlife Management, Vol. 36, No. 1, 1972, pp. 150-152.

[19] Duncan, R. R. and Boswell, F. C., "Seed Element Uptake, Grain Yield, and Bird Damage of Methiocarb-treated Sorghum Hybrids," Agronomy Journal, Vol. 73, 1981, pp. 290-292. 